\title{
Bicontrol of R. Solani AG-4 with Piperitone Product from Cymbopogon Proximus and Comparison with Bicontrol Agents (Trichoderma Spp)
}

\author{
Molan,Y.Y., Kamel, A and El-Hussieni, S. ${ }^{1}$
}

\begin{abstract}
In vitro antagonism experiments were carried out to study the ability of five biocontrol agents (: Trichoderma harzianum, T. asperellum, T. hamatum, T. virenes and $T$. viride) and fourteen plant extracts for their effects on the growth of mycelia of $R$. solani AG-4. T. harzianum was recorded the maximum inhibitor of mycelial growth followed by $T$. asperellum with average of the inhibition growth $\mathbf{5 6 . 8 2} \%$ and $\mathbf{5 4 . 4 8} \%$, respectively. Results showed also that significant antifungal activity was detected for the extracts of Cymbopogon proximus, and Ruta chalepensis.. These extracts were effective in inhibiting the mycelial growth of $R$. solani AG-4, (at amount/disc, $4 \mathrm{mg}$ ) with an average of 22.59and 21.48 respectively. Comparison studies of the inhibitory effects of piperitone, biocontrol agents and fungicide (Rizolex) on DSI, length $(\mathrm{cm})$, fresh and dry weight (gm) of bean plants were also recoded. Treatments of piperitone in the presence of $R$. solani Ag-4 showed the best control of dry root rot and stem bean disease there are also reduction effect in disease severity with average $\mathbf{1 . 0 0}$, compared with inoculated bean plants with $R$. solani AG-4 alone with average 3.65. $R$. solani AG-4. In the presence of $T$. asperellum or $T$. harzianum or Fungicide (Rizolex) were also recorded reduction in disease severity with average of 2.41 and 1.66, 1.91, respectively.
\end{abstract}

\section{INTRODUCTION}

Cymbopogon spp (Poaceae /Graminae) represent an important genus of about 120 species and several varieties. Cymbopogon species was known as a source of commercially valuable compounds (like, pipertone) which were either used as such in perfumery and allied industries or as starting materials for the synthesis of other products commonly used in perfumery Shahi and Tava, (1993). This genus was distributed in the tropical and subtropical parts of the world, more than 52 types in Africa, 45 in India, six in South America and Australia , four in Europe, and two in North America Bhan, et.al, (2005). Screening of some aromatic plants for fungitoxicity of their volatile oils, Cymbopogon pendulus, exhibited strong activity as fungicidal, completely inhibiting the mycelial growth of the tested fungi at its minimum inhibitory concentration of 200ug $/ \mathrm{ml}$, inhibiting heavy inocula of the tested fungi, Pandey, et.al., (1996). Valarini, et.al., (1994). found that The essential oil of extract of Cymbopogon citrates leaves, completely controlled mycelial growth Rhizoctonia solani on P.D.A. medium. Bankole and adebanjo,
(1995). found that the in-vitro and in-vivo efficacy of leaf extracts from 5 plants including Cymbopogon citrates were evaluated in inhibiting the growth of four plant pathogenic fungi (Macrophomina phaseolina, Fusarium moniliforme, Fusarium solani, and Botryodiplodia theobromae). Aqueous extracts of $C$. citrates completely inhibited the growth of $M$.phaseolina and B. theobromae, and also significantly reduced the growth of $F$. moniliforme and $F$. solani.

Sangwan., et al., (2000) showed that the extract of Cymbopogon grass was analysed by gas-Liqid Chromatography (GLC), GC-MS and peak -enrichment method. The oil from the Cymbopogon spp was identified, as, varian, and piperitone, the cyclic monoterpene ketone, formed a significant percentage. Singh, et.al. (1998) showed that, the essential oil extracts from varirous parts of 11 higher plants which were screened in-vitro for their fungitoxicity against fungal pathogens: Colletotrichum falcatum, Fusarium moniliforme, Ceratocystis paradoxa, Rhizotonia solani, Curvularia lunata, Periconia atropurpuria and Epicocum nigrum GC-MS analysis of Lippia alba essential oil showed Limonene (at 12.6\%) and piperitone (at 19\%) to be the major chemical constituents. Piperitone was strongly toxic even at 200ppm., Menut, et. al. (2000), found that The essential oil from leaves and flowering staks of the three Cymbopogon species ( C. citratus, C.giganteus, and C.Proximus), were analysed by GC and GC-MS, the main component of the leaf and flower esstial oil of $C$. proximus was piperitone $(59.1 \%$ and $55.6 \%$ repectively). C. proximus showed also the strongest antioxidant. Dhar, et. al.(1997). studied the variation in essential oil in five genotypes of C.Jwarancusa, from stage 1 ( green plant spikes initiated to stage 9 (30-50 leaves brown) the essential oil content ranged from 0.5 to1.64\%. The main components were Piperiton (44.9$66.8 \%$ ) and delta 2-carene( 8.3- 23.5\%). Lohani, et .al., 1986., found that of the 17 compounds identified from essential oil of Cymbopogon, Piperitone (47\%) and car2-ene (29\%)predominated. Shahi and Sen, (1989). Found that forty compounds in the essential oil extracted for herbage collected from 3 sites in western Rajasthan, the main constituent was piperitone (47.57-64.37\%). Singh, and Pathak, (1994). found that, the growth

\footnotetext{
${ }^{1}$ Department of Plant Protection- College of Food Science and Agriculture-King Saud University P.O. Box 2460 Riyadh 11451 Received October10, 2007, Accepted March12, 2008
} 
performance of three cultivars of Cymbopogon jwarancusa were proved herb yield $(21.1 \mathrm{t} / \mathrm{ha}$.) oil content (1.6\%) and oil composition (83\% piperitone ).

The well known antagonistic fungus Trichoderma spp, which is commercially available in several countries, can be used also to suppress soil-bore pathogens that cause diseases such as damping -off, root rot, stem rot, and wilting in many vegetables and has also a good effect on plant growth. Trichoderma spp can be used also to treat vegetables seed or mixing it into the soil a few days before planting as a protection against seed-borne and soil -borne fungal diseases Punja, 1997 and Kubicek et al (2001) The efficiency of $T$. harzianum as a seed treatment was assessed against stem rot of soyabean caused by Rhizoctonia solani in sterilized soil in pot tests. The lowest diseases severity index was observed when seeds were treated with $T$. harzianum plus the carrier of methyl cellulose, Dutta, and Das, (1999). Biological control of Rhizoctonia solani on Phaseolus vulgaris was investigated in greenhouse trials. Trichoderma harzianum was the most effective in-vitro and in pot experiment, also reduced post emergence root rot and proved useful controlling root rot of French bean caused by Rhizoctonia solani Mathew and Gupta (1998). Hazarika and Das, (1998) showed that Both Trichoderma harzianum and T. viride were effectively controlled root rot disease of Phaseolus vulgaris L. when applied as seed or soil treatments. Mathew and Gupta, 1998 found that Trchoderma harzianum was the most effective in vitro and in pot experiments in greenhouse trails against Rhizoctonia solani on Phaseolus vulgaris.

The objective of this study is to;

1- Compare antagonistic effect of fourteen plant extracts as natural chemical agents, and five Trichoderma spp. as biological control agents, against $R$. solani AG-4 in in-vitro studies.

2- Evaluate the disease severity index(DSI) of dry root rot and stem necrosis of bean (Phaseolus vulgaris), and some growth characteristics of affected bean plants after inoculation with $R$. solani AG-4 alone, or with biocontrol agents under greenhouse condition.

3- Comparison of the inhibitory effects of piperitone (isolatied from Cymbopogon proximus), biocontrol agents and fungicide (Rizolex) on DSI, length $(\mathrm{cm})$, fresh and dry weight (gm) and some growth characteristic of affected bean plants after inoculation with $R$. solani AG-4 under greenhouse condition..

\section{MATERIALS AND METHODS}

An isolate of Rhizoctonia solani AG-4 obtained from naturally infected bean plants from Riyadh region was used throughout this study. The isolate was maintained in the dark at $25^{\circ} \mathrm{C}$ on potato dextrose agar. Five biocontrol agents: Trichoderma harzianum, $T$. asperellum, T. hamatum, $T$. virenes and $T$. viride were isolated in the Plant Pathology Laboratory, College of Agriculture, King Saud University from local soil or plants grown in Riyadh region from commercial field and greenhouse and identified by Gary Samuels, United States Department of Agriculture, Systematic Botany and Mycology Laboratory.

Plant extracts:

\section{In - Vitro experiments:}

In-vitro experiments were carried out to study the ability of fourteen plant extracts using a randomized block design with three replicate plates for each plant extracts used in this study show in (Table 1).These plants were obtained from the local market and $100 \mathrm{~g}$ of each were ground to a fine powder and extracted twice with $90 \%$ aq. ethanol. The alcohol was evaporated under vacuum and the remaining extracts were weighed and kept in the refrigerator at $10^{\circ} \mathrm{C}$ until used.

Table1. Effect of fourteen plant extracts in three concentrations (amount/disc (1,2, $4 \mathrm{mg}$ ) against inhibition of mycelial growth of R.solani AG-4

\begin{tabular}{|c|c|c|c|}
\hline \multirow[t]{3}{*}{ Plant extracts } & \multirow{2}{*}{\multicolumn{3}{|c|}{$\begin{array}{c}\text { \%Growth inhibition } \\
\text { Amount/disc } \\
\text { Concentration }\end{array}$}} \\
\hline & & & \\
\hline & $1 \mathrm{mg}$ & $2 \mathrm{mg}$ & $4 \mathrm{mg}$ \\
\hline Artemisia abysinica & $00.00 f$ & $00.00 f$ & $00.00 d$ \\
\hline Clutia myricoides & $00.00 f$ & $00.00 f$ & $00.00 d$ \\
\hline Cymbopogon proximus & $9.57 c$ & $21.12 a$ & $22.59 a$ \\
\hline Eucalyptus spp & 00.00 & $00.00 f$ & $00.00 d$ \\
\hline Ficus palmata & $5.55 d$ & $12.06 d$ & $14.46 b$ \\
\hline Juniperus polycaepus & 00.00 & $00.00 f$ & $00.00 d$ \\
\hline Lavandula dentate & $0.48 f$ & $3.40 e$ & $5.82 c$ \\
\hline Lavandula pubescens & $1.37 e$ & $2.77 e$ & $4.72 c$ \\
\hline Lawsonia inesmis & $12.47 b$ & $13.87 c$ & $14.52 b$ \\
\hline Leptadenia protechnica & $00.00 f$ & $00.00 f$ & $00.00 d$ \\
\hline Nepeta difflersiana & $00.00 f$ & $00.00 f$ & $00.00 d$ \\
\hline Plectranthus spp & $00.00 f$ & $00.00 f$ & $00.00 d$ \\
\hline Ruta chalepensis & $15.91 a$ & $18.12 b$ & $21.48 a$ \\
\hline Sagaretia thea & $00.00 f$ & $00.00 f$ & $00.00 d$ \\
\hline
\end{tabular}

*Values within a column followed by the same letter are not significantly

$(P=0.05)$ different 
At the time of the experiment, a stock solution of each extract at a concentration of $100 \mathrm{mg} / \mathrm{ml}$ was prepared. Aliquots of 1,2 and $4 \mathrm{mg} / \mathrm{ml}$ of each extract were applied on sterilized filter paper discs and placed on the inside edge of a petri dish. Treatments also included an untreated filter paper disk (treated with 90\% ethanol/water) and served as a control. Three replicate petri dishes containing $20 \mathrm{ml}$ of PDA were used for each plant extract. Culture of Rhizoctonia solani AG-4 was grown on PDA for 1 week and $8 \mathrm{~mm}$ diameter mycelial plugs were cut from the margins of the colony. These plugs were transferred to the inside edge of a petri dish ( $8 \mathrm{~cm}$ away from filter paper disc) containing the PDA medium. Plates were also incubated at $25^{\circ} \mathrm{C}$ in the dark, and the growth area of the fungus was measured 4 days after planting.

\section{Isolation and identification of piperitone:}

The procedure for isolation and identification of piperitone from Cymbopogon proximus was done as follows: One $\mathrm{kg}$ of Cymbopogon proximus was purchased from the local market (local name "halfa bar"), and ground into a fine powder. The powder was then extracted twice with $90 \%$ aq. ethanol, filtered in a büchner funnel, and evaporated under vacuum. The oily aromatic residue $(150 \mathrm{~g})$ was refrigerated at $-10^{\circ} \mathrm{C}$ until further fractionation.

Antifungal tests showed that the extract of $C$. proximus was most effective on $R$. solani AG-4. It was therefore subjected to further fractionation to isolate the active compound(s). Five $g$ of the alcoholic extract were dissolved in the least amount of petroleum ether and subjected onto the top of a glass column $(100 \mathrm{~cm} \mathrm{x}$ $5 \mathrm{~cm}$ i.d.) packed with Silica gel 60 A (230 to 400 mesh) in petroleum ether. The column was eluted with a solvent gradient consisting $500 \mathrm{ml}$ of: petroleum ether (5 fractions), $5 \%$ ether in petroleum ether (3 fractions), $25 \%$ ether in petroleum ether (4 fractions), $50 \%$ ether in petroleum ether (4 fractions), $75 \%$ ether in petroleum ether (4 fractions), $100 \%$ ether (4 fractions), 50\% ether in acetone (5 fractions), 100\% acetone (4 fractions), $50 \%$ acetone in methanol (5 fractions), and finally 100 $\%$ methanol (8 fractions). All fractions were evaporated under reduced pressure to remove eluting solvents.

The course of chromatographic separation was followed by thin-layer chromatography (TLC) coated with silica gel and developed by the solvent mixture of hexane, ether, acetic acid (90:10:1). Spots were visualized after spraying with anisaldeheyde/sulfuric acid and heating in the oven at $100^{\circ} \mathrm{C}$. Similar fractions were combined into 10 fractions according to their profile on the thin layer chromatograms. The combined fractions were tested against $R$. solani AG-4 to determine the active fractions. The antifungal assay showed that fractions 3 and 4 possessed 100\% inhibition of fungal growth. These 2 fractions were combined and further fractionated on a reversed phase $(\mathrm{C}-18)$ column ( $250 \mathrm{~mm} \times 9 \mathrm{~mm}$ ) and eluted with $\mathrm{CH}_{2} \mathrm{Cl}_{2}: \mathrm{MeOH}: \mathrm{H}_{2} \mathrm{O}$ (90:10:1) with the aid of a medium pressure pump. Fractions were eluted $20 \mathrm{ml}$ each and collected in test tubes. Similar fractions were also combined according to their TLC separation profile. The combined fractions were then subjected to antifungal tests to determine the most effective fraction. Fractions 3-4 were found to contain the same major compound and were the most active.

Re-chromatography of these two fractions combined following the same conditions above revealed the isolation of a pure compound $(340 \mathrm{mg}$ ) of an aromatic oily substance.

This fraction was subjected to GC/MS, on an Agilent 6890 gas chromatograph equipped with a 5973 mass selective detector MSD chromatograph and attached to HP-5MS capillary column (30m, $0.25 \mathrm{~mm}$ i.d., $0.25 \mathrm{~mm}$ film) with flow rate $1 \mathrm{ml} / \mathrm{min}$ helium. Injections were split and the injector temperature was $150{ }^{\circ} \mathrm{C}$. The oven's initial temperature was $45^{\circ} \mathrm{C}$, held for $1.5 \mathrm{~min}$., then programmed to $190{ }^{\circ} \mathrm{C}$ at $30^{\circ} \mathrm{C} / \mathrm{min}$., then to $240{ }^{\circ} \mathrm{C}$ at $3{ }^{\circ} \mathrm{C} / \mathrm{min}$. The MSD interface temperature was $280^{\circ} \mathrm{C}$ and the dwell time in the mass analyzer was 40 msec/ion. Peak identification was performed by comparing the retention times of each peak with those of known standard compounds and by the NIST 98 mass spectral library. The mass spectral library showed that the isolated compound has a similar mass spectrum to piperitone, a known monterpenoid, with the molecular formula $\mathrm{C}_{10} \mathrm{H}_{14} \mathrm{O}$.

Astandard substance of piperitone was purchased from Chem Service, USA then injected to the GC/MS system and it gave the same retention time and mass spectral fragmentation as the isolated active compound alone and upon admixture of both substances. Therefore, the isolated compound responsible for the antifungal activity of Cymbopogon proximus is identified as piperitone.

\section{1- Laboratory experiments:}

In vitro antagonism experiments were carried out to study the ability of five biocontrol agents show in Table (2) for their effects on the growth of mycelia of $R$. solani AG-4, following the dual culture technique (Hudec, 2000),. The experiment was performed twice. A mycelial disc (8mm diameter) from 4-day-old cultures of $R$. solani AG-4 was placed on the inside edge of a petri dish. Then a mycelial disc (8mm diameter) obtained from 4-day-old cultures of each Trichoderma spp. was placed $8 \mathrm{~cm}$ away from the inoculum of the pathogen, the plates were incubated at $25^{\circ} \mathrm{C}$. The growth 
area of the fungus was measured 4 days after planting. The growth inhibition of $R$. solani AG-4 was calculated in relation to the growth of the control in all treatments according to the method of Abdulsalam et. al 1993. (\%, Growth inhibition $=100$ - fungal growth (treated) $X 100$ / fungal growth (control) Data were then analyzed using the Statistical Analysis System software (SAS Institute Inc.,1988). Analysis of variance and least significance differences (LSD) $\mathrm{P}=0.05$ were used to detect differences among means.

Table2. Effect of five biocontrol agents on inhibition of mycelial growth of R.solani AG-4

\begin{tabular}{ll}
\hline Biocontrol agent: & $\begin{array}{l}\text { \%Growth } \\
\text { inhibition }\end{array}$ \\
\hline $\boldsymbol{T}$. asperellum & $54.48 \mathrm{ab}$ \\
$\boldsymbol{T}$. harzianum & $56.82 \mathrm{a}$ \\
$\boldsymbol{T}$.hamatum & $52.62 \mathrm{ab}$ \\
$\boldsymbol{T}$. viride & $50.13 \mathrm{~b}$ \\
$\boldsymbol{T}$. virens & $43.62 \mathrm{c}$ \\
\hline
\end{tabular}

*Values within a column followed by the same letter are not significantly $(P=0.05)$ different

\section{2- Greenhouse experiments :}

Two experiment designs in a randomized complete block with six replicates was carried out in the greenhouse at the college of Food Science and Agriculture, King Saud University . Treatments of the first experiment show in (Table. 3) to evaluate the disease severity of dry root rot and stem necrosis of bean (Phaseolus vulgaris), and determine some of the growth characteristic of affected bean plants after inoculation with $R$. solani alone or with biocontrol agents.

Table3. Comparison of the inhibitory effects of plant extracts and bicontrol agent on growth of $R$. solani AG-4

\begin{tabular}{lcc}
\hline Treatment & $\begin{array}{c}\text { Amount/disc } \\
\text { Concentration }\end{array}$ & $\begin{array}{l}\text { \%Growth } \\
\text { inhibition } \\
\text { of } \boldsymbol{R} \text {. solani }\end{array}$ \\
\hline Plant Extracts: & & \\
Cymbopogon proximus & $4 \mathrm{mg}$ & $22.59 \mathrm{~d}$ \\
Ficus palmate & $4 \mathrm{mg}$ & $14.46 \mathrm{e}$ \\
Lavandula dentate & $4 \mathrm{mg}$ & $5.82 \mathrm{f}$ \\
Lavandula pubescens & $4 \mathrm{mg}$ & $4.72 \mathrm{f}$ \\
Lawsonia inesmis & $4 \mathrm{mg}$ & $14.52 \mathrm{e}$ \\
Ruta chalepensis & $4 \mathrm{mg}$ & $21.48 \mathrm{~d}$ \\
Biocontrol agents: & & $54.48 \mathrm{a}$ \\
T. asperellum & -- & $56.82 \mathrm{ab}$ \\
T. harzianum & -- & $52.62 \mathrm{ab}$ \\
T .hamatum & -- & $50.13 \mathrm{~b}$ \\
T. viride & -- & $43.62 \mathrm{c}$ \\
$T$. virens & -- & \\
\hline
\end{tabular}

*Values within a column followed by the same letter are not

significantly different according to the L.S.D. test $(P=0.05)$
Treatments of the second experiment show (in table 4) to compare the inhibitory effects of plant extracts, bicontrol agent and fungicide (Rizolex ) aganist $R$. solani AG-4 causing dry root rot and stem of bean. a) Inoculum of $R$. solani AG-4

Inoculum of $R$. solani AG-4 was prepared by the whole grain method of (Gaskill, 1968). The inoculum was thoroughly mixed added to the pot soil surface at the rate of $0.5 \%$ w/w per pot (Papavizas and Dvery, 1962) and then covered with a thin layer of sand. The control consisted of sterilized ground wheat grains with no pathogen.

\section{a) Inoculum of $R$. solani AG-4}

Inoculum of $R$. solani AG-4 was prepared by the whole grain method of (Gaskill, 1968). The inoculum was thoroughly mixed added to the pot soil surface at the rate of $0.5 \% \mathrm{w} / \mathrm{w}$ per pot (Papavizas and Dvery, 1962) and then covered with a thin layer of sand. The control consisted of sterilized ground wheat grains with no pathogen.

\section{b) Seed treatment:}

Bean seeds (Phaseolus vulgaris L.) were surface disinfested in $1.5 \%$ sodium hypochlorite solution for 10 min, washed in sterilized water and air dried. Conidia of Trichoderma spp 7 day old Petri cultures grown on Potato Dextrose Agar, were flooded with sterile water and spores were scraped from the agar surface, sieved through three layers of sterile cheesecloth and counted in a haemacytomter. Spores were then resuspended in sterile water containing $1.4 \% \mathrm{CMC}$ to give a final concentration of $1.0 \times 10^{8}$ spores per ml. Bean seeds were pergerminated in the CMC spore suspension for 24 $\mathrm{h}$ at $25^{\circ} \mathrm{C}$ before sowing. The fungicide( Rizolex) was applied at doses recommended by the manufacturers to simulate the actual field doses. Four bean seeds were planted in $12 \mathrm{~cm}$ diameter plastic pots containing steam sterilized soil. The soil consist of clay loam and sand in a 1:1 ratio by volume. Control pots containing autoclaved soil alone were included for comparison. Temperatures during the experiment ranged from 18-27 ${ }^{\circ} \mathrm{C}$. Disease Severity Index (DSI) based on a scale 0-5 where $0=$ No apparent infection, $1=$ light discoloration of crown and root tissue approximately $10 \%, 2=11$ $20 \%$ crown and root tissue covered with dark brown lesion, $3=21-50$ crown and root tissue covered with large dark brown lesion, $4=51-75 \%$ crown and root tissue covered with large lesion and decay of root tissue, and $5=$ dead plant (Baudion, 1988). At the end of experiment differences parameter of plant growth (plant height, fresh and dry weight ( $\mathrm{g}$ ) of root and shoots) were assessed. Data were analyzed using the Statistical Analysis System ( SAS Institute,Inc.1988) Analysis of variance and Least Significance Difference values 
Table4. Effects of biocontrol agents (T. asperellum (T.1) and T. harzianum (T.2) on DSI, length (cm), fresh and dry weight (gm) of bean plants after inoculation with $R$. solani AG-4

\begin{tabular}{lcccccc}
\hline Treatment & $* *$ DS & Length & \multicolumn{2}{c}{ Fresh weight $(\mathbf{g})$} & \multicolumn{2}{c}{ Dry weight $(\mathbf{g})$} \\
\cline { 4 - 7 } & & $(\mathbf{c m})$ & Shoot & Root & Shoot & Root \\
\hline Control & 00.00 & $20.43 * \mathrm{a}$ & $13.75 \mathrm{a}$ & $1.85 \mathrm{a}$ & $3.95 \mathrm{a}$ & $0.69 \mathrm{a}$ \\
T. asperellum (T.1) & 00.00 & $19.23 \mathrm{a}$ & $13.55 \mathrm{a}$ & $1.76 \mathrm{a}$ & $3.92 \mathrm{a}$ & $0.65 \mathrm{a}$ \\
T. harzianum (T.2) & 00.00 & $19.90 \mathrm{a}$ & $14.17 \mathrm{a}$ & $1.93 \mathrm{a}$ & $4.20 \mathrm{a}$ & $0.70 \mathrm{a}$ \\
R. solani + (T.1) & $1.66 \mathrm{~b}$ & $17.40 \mathrm{~b}$ & $9.55 \mathrm{c}$ & $1.30 \mathrm{~b}$ & $2.95 \mathrm{~b}$ & $0.72 \mathrm{a}$ \\
R. solani + (T.2) & $1.53 \mathrm{~b}$ & $18.96 \mathrm{~b}$ & $11.10 \mathrm{~b}$ & $1.45 \mathrm{~b}$ & $3.00 \mathrm{~b}$ & $0.50 \mathrm{~b}$ \\
R. solani & $3.58 \mathrm{a}$ & $15.23 \mathrm{c}$ & $8.03 \mathrm{c}$ & $1.05 \mathrm{c}$ & $1.41 \mathrm{c}$ & $0.30 \mathrm{c}$ \\
\hline
\end{tabular}

*Values within a column followed by the same letter are not significantly $(P=0.05)$ different

** DS $=$ Disease Severity

(LSD), $(\mathrm{P}=0.50)$ were used to detect differences among treatment means.

\section{RESULTS AND DISCUSSIONS}

Results showed that significant antifungal activity was detected for the extracts of Cymbopogon proximus, and Ruta chalepensis.. These extracts were found effective in inhibiting the mycelial growth of $R$. solani AG-4, (at Amount/disc, $4 \mathrm{mg}$ ) with an average of 22.59and 21.48 respectively. Lavandula spp was found to be a weaker antifungal agent under the tested concentration, (at Amount/disc, $4 \mathrm{mg}$ ) which recorded only $4.72 \%$ and $5.82 \%$ (L. pubescens and L.. dentate, respectively), mycelial growth inhibition of $R$. solani AG-4. No evidence of growth inhibition of $R$. solani when used plant extracts of Artemisia abysinica, Clutia myricoides, Eucalyptus spp, Juniperus polycaepus, Leptadenia protechnica, Nepeta difflersiana, Plectranthus spp, and Sagaretia thea . (Table 1) Other studies support these results in which Cymbopogon pendulus, exhibited strong activity as fungicidal, completely inhibiting the mycelial growth of the tested fungi at its minimum inhibitory concentration of 200ug $/ \mathrm{ml}$, inhibiting heavy inocula of the tested fungi, ( Pandey, 1996). The in-vitro and in-vivo efficacy of leaf extracts from 5 plants including Cymbopogon citrates were evaluated in inhibiting the growth of four plant pathogenic fungi (Macrophomina phaseolina, Fusarium moniliforme, Fusarium solani, and Botryodiplodia theobromae). Aqueous extracts of $C$. citrates completely inhibited the growth of M.phaseolina and $B$. theobromae, and also significantly reduced the growth of $F$. moniliforme and F. solani Bankole and adebanjo, (1995). Data in (Table:2) show significant differences between all treatments in the growth inhibition of $R$. solani AG-4. All tested biocontrol agents except $T$. viride were the most effective in inhibiting the pathogen growth as compared with tested plant extracts. $T$. harzianum, T. asperellum and $T$.hamatum were found highly effective against $R$. solani AG-4, than other tested Trichoderma spp. in the dual culture technique. $T$. harzianum was recorded the maximum inhibition of mycelial growth followed by $T$. asperellum with average of the inhibition growth $56.82 \%$ and $54.48 \%$, respectively. Durman et al 1999 suggested that dual cultures in Petri dishes may be useful for detecting isolates as biological control agents. Chet, I., (1987). showed that the species of Trichoderma are commercially applied as biological control agents against fungal pathogens.Plant pathogenic fungi such as Botryodiplodia, Colletotrichum, Gliophalotrichum, Fusarium, Pythium, Rhizoctonia, Sclerotium spp. and others were successfully controlled by Trichoderma spp. Sivakumar et. al.(2000) and Sanjay et,al.,(2001) found that the inhibition of $R$. solani AG-4 by Trichoderma spp., especially $T$. harzianum, T. asperellum and $T$ .hamatum, which provided evidence of its applicability to control this pathogen. Data in (table.3) show the comparison of the inhibitory effects of six plant extracts at the concentration ( $4 \mathrm{mg}$, amount/disc ) and bicontrol agent on inhibition growth of $R$. solani AG-4. Significant antifungal activity was detected for the extracts of Cymbopogon proximus, and Ruta chalepensis with average of the inhibition growth of $R$. solani AG-4, $22.59 \%$ and $21.48 \%$, respectively) .T. harzianum, $T$. asperellum and $T$.hamatum were found highly effective on inhibition growth $R$. solani AG-4 with average of the inhibition growth $56.82 \%, 54.48 \%$, and $50.13 \%$ respectively.

Data in ( Table. 4), show the effects of biocontrol agents: (T. asperellum (T.1) and T. harzianum (T.2) on diseases severity index, plant length $(\mathrm{cm})$, fresh and dry weight $(\mathrm{gm})$ of bean plants after inoculation with $R$. solani AG-4. Symptoms and signs of disease on inoculated bean plants were identical of those observed on naturally infected plants. Dark brown in the crown region or just below the soil surface, frequently girdled the basal stem causing stem and dry root rot bean disease. Disease Severity Index showed highly significant differences among all treatments (Table.4). T. harzianum (T.2) plus $R$. solani AG-4 and $T$. 
asperellum (T.1) plus $R$. solani were the most effective to control disease with the average of disease severity of 1.53 and 1.66, respectively, as compared with inoculated bean plants with $R$. solani AG-4 alone with the average of disease severity of 3.58. Significant differences in plant height were observed, plants inoculated with $R$. solani AG-4 alone showed reduction in plant height $(\mathrm{cm})$ with average 15.23 and reduction in fresh and dry weight $(\mathrm{g})$ of shoot and root with the average of $8.03,1.05,1.41$, and 0.30 respectively, as compared with inoculated bean plants with $R$. solani AG-4 in the presence of $T$. harzianum (T.2), which recorded the highest value in fresh and dry weight $(\mathrm{g})$ of shoot and root with the average of 11.10,1.45,3.00, and 0.50 respectively. Data in ( Table. 5), show the comparison of the inhibitory effects of piperitone , biocontrol agents and fungicide (Rizolex) on DSI, length $(\mathrm{cm})$, fresh and dry weight $(\mathrm{gm})$ of bean plants after inoculation with $R$. solani AG-4. Disease Severity Index showed highly significant differences among all treatments (Table.5). Treatments of piperitone in the presence of $R$. solani Ag-4 showed the best control of dry root rot and stem bean disease and reduction effect in disease severity with average 1.00 , as compared with inoculated bean plants with $R$. solani AG-4 alone with average 3.65. $R$. solani AG-4 in the presence of $T$. asperellum or $T$. harzianum or Fungicide (Rizolex) were also recorded reduction in disease severity with average of 2.41 and 1.66, 1.91, respectively. Significant differences in plant height were observed, plants inoculated with $R$. solani AG-4 alone showed reduction in plant height $(\mathrm{cm})$ with average 15.33 and reduction in fresh and dry weight $(\mathrm{g})$ of shoot and root with the average of $6.13,2.67,1.40$, and 0.20 respectively, as compared with inoculated bean plants with $R$. solani AG-4 in the presence piperitone in plant height $(\mathrm{cm})$ with average 27.50 and recorded considerable value in fresh and dry weight $(\mathrm{g})$ of shoot and root with the average of $16.00,7.10,2.10 \mathrm{c}$, and 1.00 , respectively. Treatments of $T$. harzianum was also recorded considerable value in plant height $(\mathrm{cm})$ with average 26.50 and recorded considerable value in fresh and dry weight $(\mathrm{g})$ of shoot and root with the average of 13.00 , $6.80,2.90$ and 0.87 , respectively.

Table5. Comparison of the inhibitory effects of piperitone, biocontrol agents and fungicide (Rizolex) on DSI, length $(\mathrm{cm})$, fresh and dry weight (gm) of bean plants after inoculation with $R$. solani AG-4

\begin{tabular}{|c|c|c|c|c|c|c|}
\hline \multirow[b]{2}{*}{ Treatment } & \multirow[t]{2}{*}{$* *$ DSI } & \multirow{2}{*}{$\begin{array}{l}\text { Length } \\
(\mathbf{c m})\end{array}$} & \multicolumn{2}{|c|}{ Fresh weight (g) } & \multicolumn{2}{|c|}{ Dry weight (g) } \\
\hline & & & Shoot & Root & Shoot & Root \\
\hline Control & $00.00 \mathrm{e}$ & $29.20 \mathrm{a}$ & $14.30 \mathrm{abc}$ & $7.06 \mathrm{ab}$ & $3.00 \mathrm{~b}$ & $1.20 \mathrm{a}$ \\
\hline $\begin{array}{l}\text { Piperitone } \\
\text { (4 ppm) }\end{array}$ & $00.00 \mathrm{e}$ & $29.30 \mathrm{a}$ & $15.66 \mathrm{a}$ & $7.40 \mathrm{a}$ & $3.40 \mathrm{a}$ & $1.40 \mathrm{a}$ \\
\hline $\begin{array}{l}\text { Piperitone } \\
\text { (blank) }\end{array}$ & $00.00 \mathrm{e}$ & $29.33 \mathrm{a}$ & $14.33 \mathrm{abc}$ & $7.26 \mathrm{a}$ & $2.80 \mathrm{~b}$ & $1.35 \mathrm{a}$ \\
\hline T. asperellum & $00.00 \mathrm{e}$ & $28.16 \mathrm{ab}$ & $15.33 \mathrm{ab}$ & $6.43 \mathrm{~b}$ & $3.10 \mathrm{a}$ & $0.99 \mathrm{~b}$ \\
\hline T. harzianum & $00.00 \mathrm{e}$ & $27.50 \mathrm{bc}$ & $16.00 \mathrm{a}$ & $7.23 \mathrm{a}$ & $3.60 \mathrm{a}$ & $1.30 \mathrm{a}$ \\
\hline $\begin{array}{l}\text { Rizolex } \\
\text { ( Fungicide) }\end{array}$ & $00.00 \mathrm{e}$ & $16.33 \mathrm{e}$ & $8.50 \mathrm{e}$ & $4.30 \mathrm{~d}$ & $2.30 \mathrm{c}$ & $0.45 \mathrm{c}$ \\
\hline $\begin{array}{l}\text { Piperitone } \\
+R \text {. solani }\end{array}$ & $1.00 \mathrm{~d}$ & $27.50 \mathrm{bc}$ & $11.66 \mathrm{~d}$ & $5.50 \mathrm{c}$ & $2.10 \mathrm{c}$ & $0.75 \mathrm{~b}$ \\
\hline $\begin{array}{l}\text { T. asperellum } \\
+ \text { R. solani }\end{array}$ & $2.41 \mathrm{~b}$ & $24.83 \mathrm{~d}$ & $13.00 \mathrm{~cd}$ & $6.80 \mathrm{ab}$ & $2.80 \mathrm{~b}$ & $0.87 \mathrm{~b}$ \\
\hline $\begin{array}{l}\text { T. harzianum } \\
+ \text { R. solani }\end{array}$ & $1.66 \mathrm{c}$ & $26.50 \mathrm{c}$ & $13.66 \mathrm{bc}$ & $7.10 \mathrm{ab}$ & $2.90 \mathrm{~b}$ & $1.00 \mathrm{~b}$ \\
\hline $\begin{array}{l}\text { Rizolex } \\
+R . \text { solani }\end{array}$ & $1.91 \mathrm{c}$ & $15.33 \mathrm{e}$ & $7.66 \mathrm{ef}$ & $3.86 \mathrm{~d}$ & $1.60 \mathrm{~d}$ & $0.72 \mathrm{c}$ \\
\hline R. solani & $3.65 \mathrm{a}$ & $15.33 \mathrm{e}$ & $6.13 \mathrm{f}$ & $2.67 \mathrm{e}$ & $1.40 \mathrm{~d}$ & $0.20 \mathrm{~d}$ \\
\hline
\end{tabular}

*Values within a column followed by the same letter are not significantly different according to the L.S.D. test $(P=0.05)$

DSI $=$ Disease Severity Index 


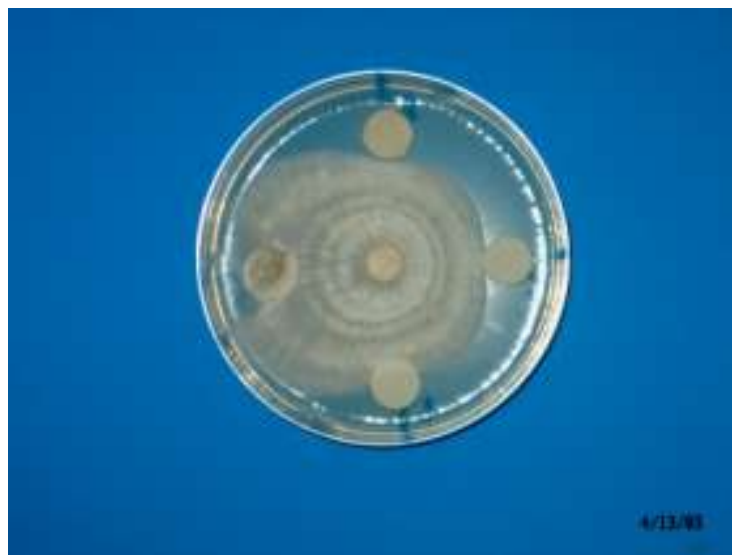

a)

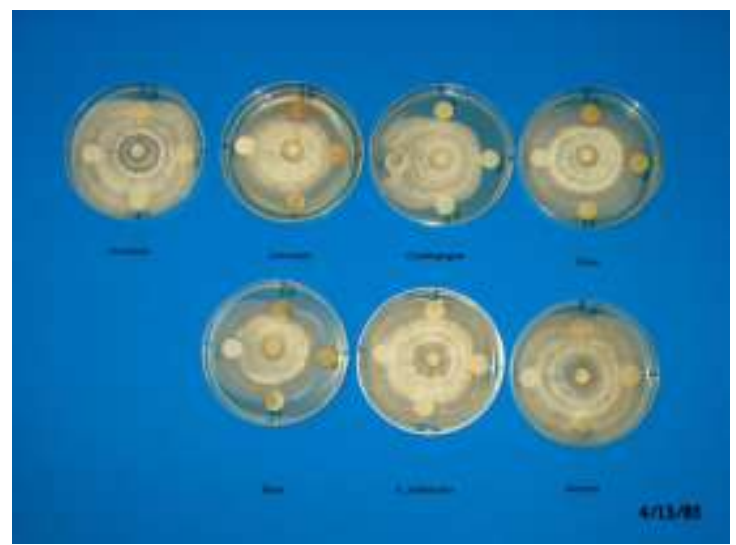

C)

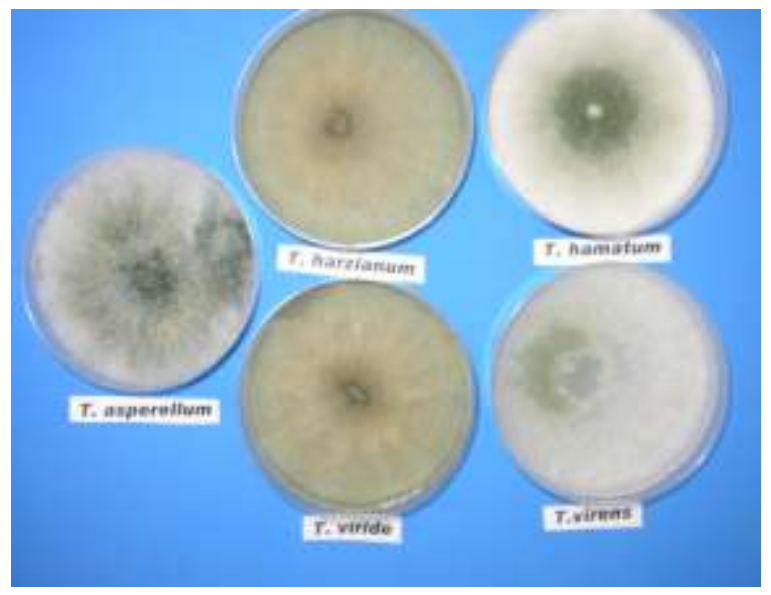

E)

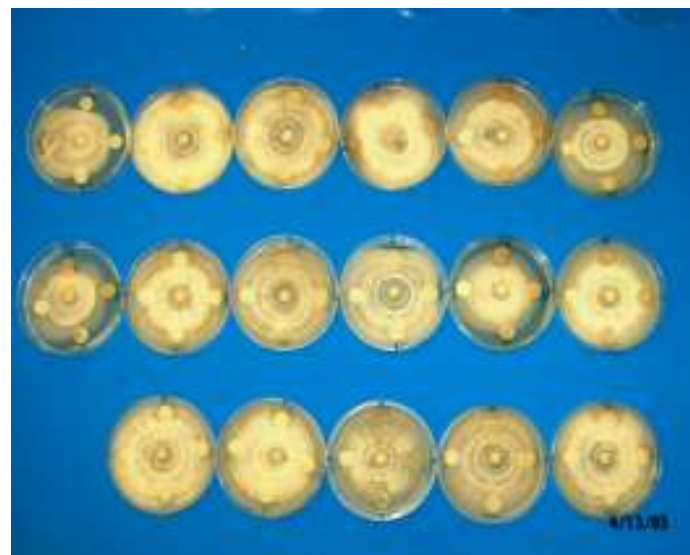

b)

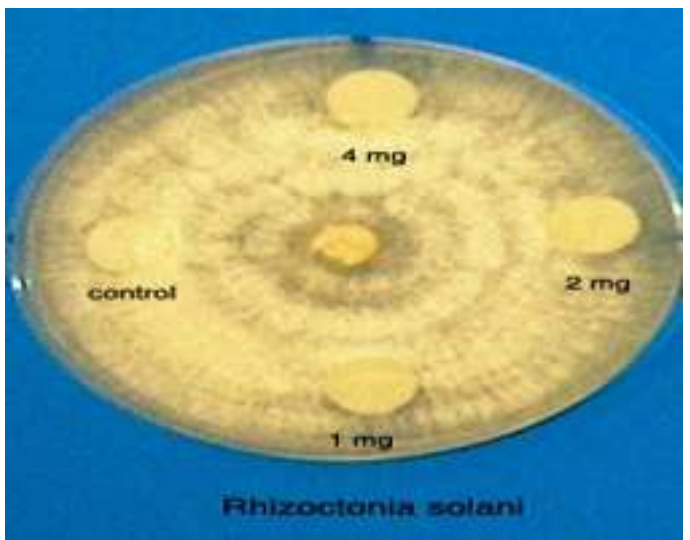

D)

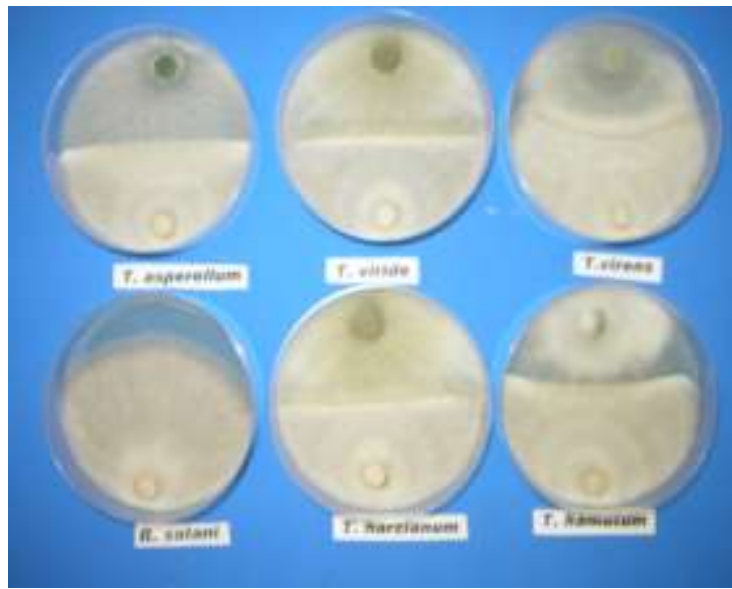

F)

Plate 1. a) Effect of Cymbopogon proximus on inhibition of mycelial growth of R.solani Ag-4.

b) Effect of tested plant extracted in three concentration (amount /disc(1,2,4 mg) on inhibition of mycelial growth of R.solani Ag-4.

C) Active tested plant extracts.

D) Non active plant extract of Leptadenia protechnica

E) Five tested biocontrol agents : T. asperellum, T. harzianum, T.hamatum, T. viride, and T.virens

F) Effect of five biocontrol agents on inhibition of mycelial growth of R.solani 


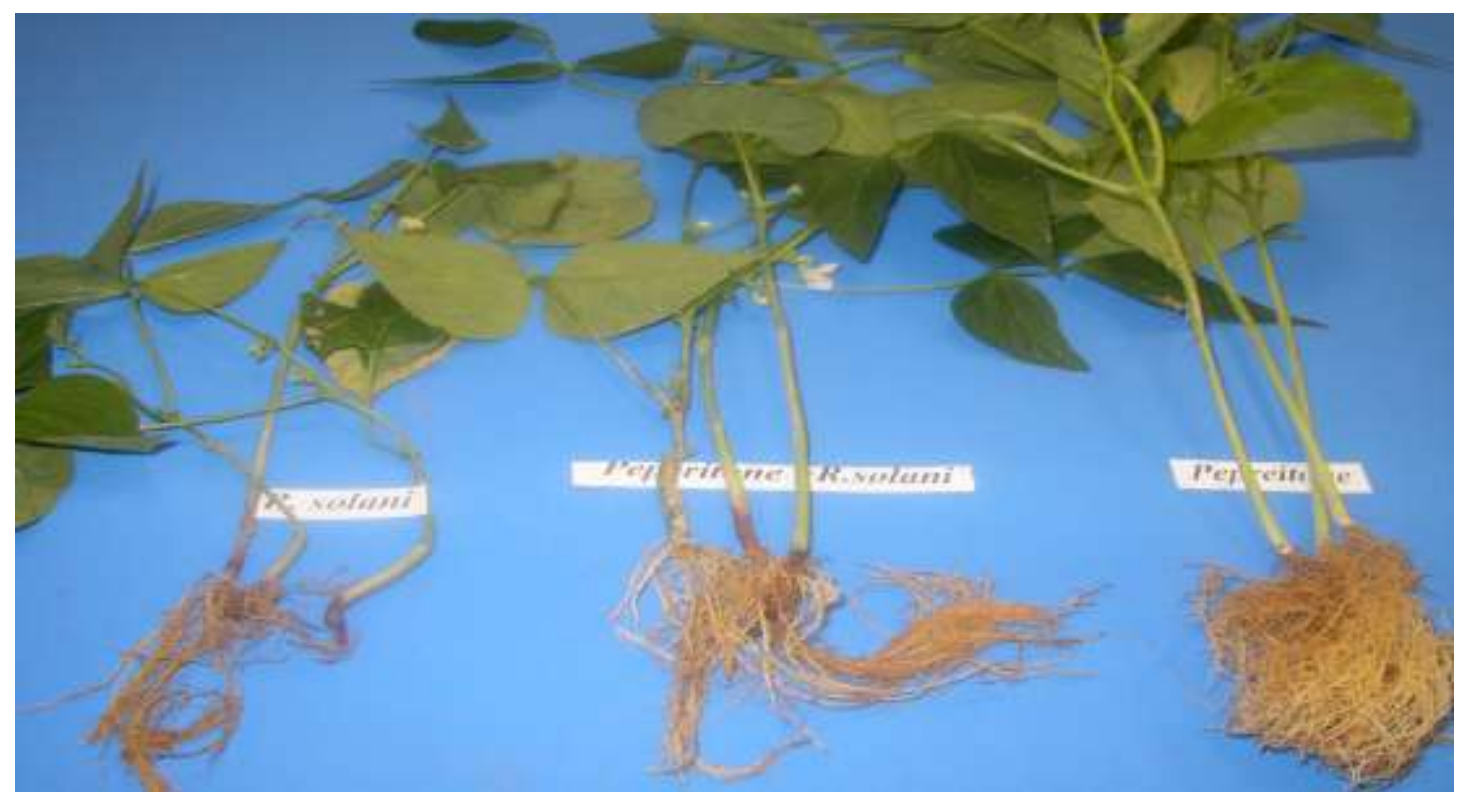

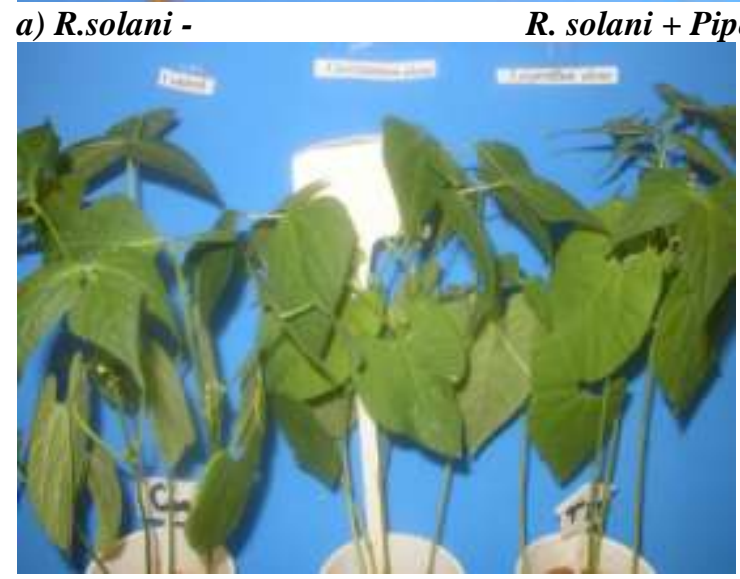

a) control- $\quad T$. harzianum - T. asperellum

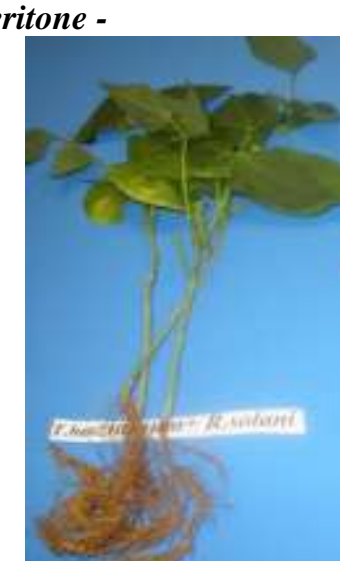

b) T. harzianum

$+R$. solani
Piperitone

\section{T. harzianum alone}

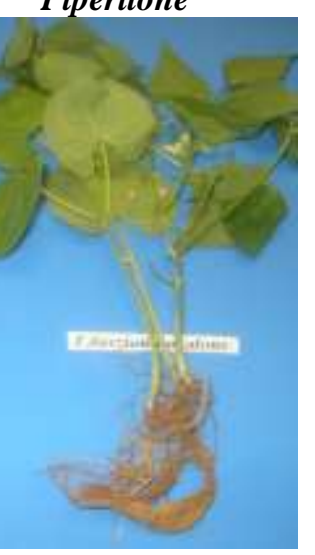




\section{REFERENCES}

Abdulsalam, K.S., Abdel-Megeed, M.I., Rezk, M.A., Najeeb, M.A. 1993. tiveness of certain fungicides against soil borne fungi associated with Wijame date palm trees." The Third Symposium on The Date-

Palm In Saudi Arabia. Date- palm research center King Faisal University, Al-Hassa . vol. II. 99-105.

Bankole, S.A.,Adebanjo.A.1995. Inhibition of growth of some plant pathogenic fungi using from some Nigerian plants. International Journal of Tropical Plant Diseases. 13: 91-95.

Bhan,M.K., Pal, S., Rao,B.L., Dhar,A.K.and Kank,M.S. 2005 GGE Biplot Analysis of oil yield in Lemongrass(Symbopogon spp.). Journal of New Seed. 7: (2). http. //www haworthpress. com/web/JNS.

Buadion,A.B.1988.Laboratory exrises in plant pathology.An instructional Kit. American phytopathological Society.St.Paul.MN.

Chet, I. Trichoderma: application, mode of action and potential as a biocontrol agent of soilborne plant pathogenic fungi. In: Chet, I. (ed.). Innovative approaches to plant disease control (1987), pp. 137-160. Wiley, New York.

Dhar, R.S., Dhar, A.K. and Sapru, D.R. 1997. Ontogentic variation in the essential oil concentration and its constituents in the five genotype of Cymbopogon jwarancusa (jones) Schutz.

Dutta,P. and Das, B.C.1999. Control of Rhizoctonia solani in soybean (Glycine max) by faryard manure culture of Trichoderm harzianum. Indian Journal of Agriculture science 69:596-598.

Gaskill,J.O. 1986. Breeding for Rhizoctonia resistance in sugar beet .J.Am,Soc. Sugar beet. Technol. 15: 107-119.

Hazarika,D.K., Das,K.K.1998. Biological management of root rot of French bean ( Phaseolus vulgaris L.) caused by Rhizoctonia solani. Plant Disease Research 13: 101-105.

Hudec, K. 2000. Influence of temperature on Trichoderma harzianium antagonistic activity against Microdochium nivale, Fusarium culmorum and $F$ equiseti under in vitro condition. Acta Fytotechnica et Zootechnica. 3: 98-100.

Kubicek, C.P., Mach, R.I., Peterbauer, C.K., and Lorito,M.2001.Trichoderma : from genes to Biocontrol. Journal of Plant Pathology 83: 11-23.

Lohani, H, Bisht, J.C., Melkani,,A.B., Mathela, A.B. Mathela, D.K., and Dev,C.C. 1986. Chemical composition of essential oil of Cymbopogon stracheyi (hook.f.)Raiz\&Jain. 1986. Indian Perfumer 30: 447-452.

Mathew, K.A., and Gupta, S.K. 1998. Biological control of root rot of French bean caused by Rhizoctonia solani. Journal of Mycology and Plant Pathology. 28: 202-205.
Menut,C., Bessiere,J.M., Samate, D.,Djibo, A.K., Buchbauer,,G. and Schopper,B.2000. Atromtic plants of tropical west Africa XI. Chemical composition, Antioxidant and antiradical properties of the essential oils of three Cymbopogon species from Burkina Faso. Journal of Essential Oil Research 12: 207-212.

Pandey, M.C., Sharma, J.R., Anupam, J.R., and Dikshit, A.D. 1996. Antifungal evaluation of the essential oil of Cymbopogon pendulus. Flavour and Fragrance Journal 11: $257-260$.

Papavizas,G.C., and Davey, C.B.1962. Isolation and pathogenicity of Rhizoctonia saprophtically existing in soil.J. of Phytopathology 52: 834-840.

Punja, Z.K. 1997.Comparative efficacy of bacteria, fungi and yeast as biological control agents for diseases of vegetable crops. Canadian Journal of Plant Pathology 19: 315-323.

Sangwan,N.S., Naqvi,A.A., Sangwan, R.S., Kumar,S.(ed), Kukreja, A.K. (ed)., Dwived.S.(ed)., and Singh,A.K.2000. A novel Chemotype of aromatic grass Cymbopogon.

Sanjay, A., Kaushik, J.C., Arya, S. (2001)“Efficacy of Trichoderma species and Gliocladium virens as biocontrol agents against damping-off of forests nurseries." Plant disease Research, 16:1, 46-51.

SAS,Institute.1988.SAS/STAT User"s Guide release 6.03.SAS.Institute.Inc.Cary,NC. 1028pp.

Shahi, A.K. and Tava,A. 1993. Essential oil composition of three Cymbopogon species of Indian Thar Deasert. J.Essent.Oil Res. 5: 639-643.

Shahi, A.K., and Sen,D.N.1989. Note on Cymbopogon Jwarancusa (Jones) Schult, source of piperitone in Thar desert. Current Agriculter.13:99-101.

Sing, S.P.Rao, and Upadhyaya, P.P. 1998.Fungitoxicity of essential oils of some aromatic plants against sugarcane pathogens. Sugar Cane. 1998. No.2, 14-17.

Singh, R.S., and Pathak, M.G. 1994. Variability in herb yield and volatile constituents of Cymbopogon jwarancusa (Jones)Schult. cultivars. Industrial Crops Products. 2: 197199.

Sivakumar, R.S., Wilson, W.,Wijesundera, R.L.C., Marikar, F.M.T. and Abeyesekere, M.. 2000 "Antagonistic effect of Trichoderma harzianum on postharvest pathogens of Rambutan( Nephelium lappaceum)."Phytoparasitica,,28: (3)1-8.

Valarini,P.J., Frighetto, R.T.S., and Melo,I.S.1994. The effect of medicinal herbCymbopogon citrates on control of phytopathogenic fungi in a bean crop. Revista de Agriculture Piracicaba 69: 139-150. 


\section{الملخص العربي}

المكافحة الحيوية للفطر ريزوكتونيا بواسطة البريتون المستخلص من نبات الحلفا بر والمقارنة بفطريات المكافحة الحيوية التابعة للجنس تريكوديرما

$$
\text { يونس مولان، علاء كامل،صلاح الحسيني }
$$

سجلت دراسة مقارنة في تأثير الببريتون والعوامل الحيوية والمبيد

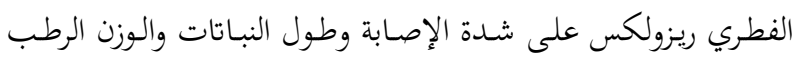

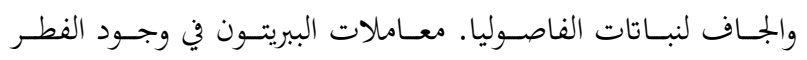

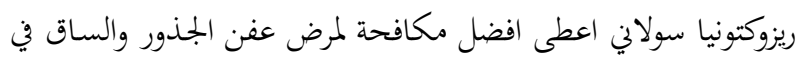

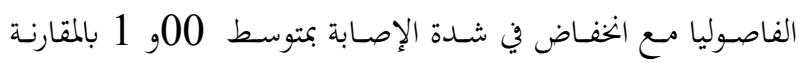

بنباتات الفاصوليا الملقحة بالفطر ريزوكتونيا بمفرده بكتوسط 65 و و 3.

في وجود الفطر تريكوديرما اسبريليم او هيزيانيم او في وجودود المبيديد

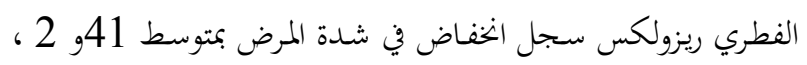

66 و 1 ، ، 91 و 1 على التوالي.
اجريت تحارب تضاد معملية لدراسة قدرة خمس عوامل حيوية (

تريكوديرما هيرزيانيم - أسبريليم - هماتم - فيرنس-فيريديد)، 14

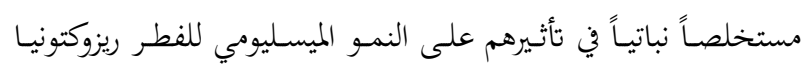

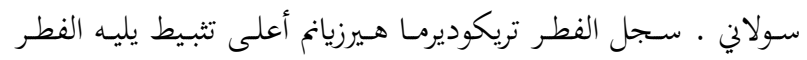

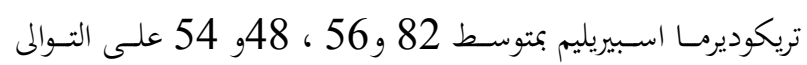
ظهرت النتائج ايضاً فروق معنوية في نشاط التضاد الفطري لمستخلص نبات الحلفابر ونبات Ruta حيث وجدت اهنا فعالة في تثبيط النمو

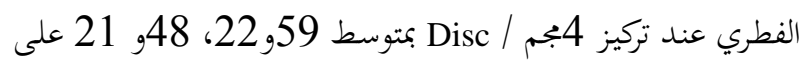

